Submitted to: Sociobiology

\title{
2 Morphology and ultrastructure of the pro- and postpharyngeal 3 glands in workers of Brachyponera sennaarensis
}

\author{
4 J. BILLEN $^{1}$ \& M.S. AL-KHALIFA ${ }^{2}$
}

$5{ }^{1}$ Zoological Institute, University of Leuven, Naamsestraat 59, Box 2466, B-3000 Leuven 6 (Belgium)

$7 \quad{ }^{2}$ Department of Zoology, College of Science, P.O. Box 2455, King Saud University, Riyadh 811451 (Saudi Arabia)

Running title: Pro- and postpharyngeal glands of Brachyponera sennaarensis

\section{Contact address:}

Prof. Johan Billen, K.U.Leuven, Zoological Institute, Naamsestraat 59, box 2466, B-3000 Leuven, Belgium

Tel : (32) 16323975

Fax : (32) 16324575

E-mail johan.billen@bio.kuleuven.be 


\begin{abstract}
The pro- and postpharyngeal glands of Brachyponera sennaarensis both appear as globular formations at a general anatomical level. However, only for the propharyngeal gland do these formations correspond with spherical secretory cells with diameters of 30-40 $\mu \mathrm{m}$. For the lobed postpharyngeal gland, in contrast, this globular appearance is caused by the bulbous protrusions of the epithelial cells. This lobed appearance and globular cell shape also occur in the postpharyngeal glands of other Ponerinae and thus may represent a phylogenetic character. At the ultrastructural level, the propharyngeal gland cells are characterized by a well-developed granular endoplasmic reticulum, which is in agreement with its presumed production of digestive enzymes. The postpharyngeal gland cells contain a well-developed smooth endoplasmic reticulum, which allows the production of a non-proteinaceous secretion.

Keywords: Brachyponera sennaarensis, propharyngeal gland, postpharyngeal gland, morphology, ultrastructure.
\end{abstract}




\section{Introduction}

Brachyponera sennaarensis, also known as the samsum ant, is a common ponerine species in the savannas of eastern Africa. It is rather exceptional among the Ponerinae as it mainly feeds on plant seeds (Levieux \& Diomande, 1978), although it also hunts for small prey (Lachaud \& Déjean, 1994). In recent years, several papers have reported on its eastward range expansion into the Middle East (Paknia et al., 2006; Al-Khalifa et al., 2010; Wetterer, 2013). Besides the geographical expansion as such, $B$. sennaarensis is also becoming increasingly well-known because of its painful sting, which may cause severe anaphylactic shock in humans (Al-Anazi et al., 2009). We started a project to study the general exocrine system of this ant, of which the present paper reports on the pro- and postpharyngeal glands in the head.

\section{Material and methods}

Workers of Brachyponera sennaarensis were collected from a colony in the wild, nesting between the root system of a date palm tree at Naa'm, Huata bani Tamim region in the south of Riyadh, Saudi Arabia. Both anterior head portions and dissected pharyngeal glands were fixed in cold $2 \%$ glutaraldehyde, buffered with $50 \mathrm{mM}$ Na-cacodylate and $150 \mathrm{mM}$ saccharose. This was followed by postfixation in $2 \%$ osmium tetroxide and dehydration through a graded acetone series. Tissues were embedded in Araldite resin, and sectioned with a Leica EM UC6 ultramicrotome. Serial semithin sections with a thickness of $1 \mu \mathrm{m}$ were stained with methylene blue and thionin, and examined with an Olympus BX-51 light microscope. Thin sections with a thickness of $70 \mathrm{~nm}$ were double stained with uranyl acetate and lead citrate, and viewed in a Zeiss EM900 electron microscope. Carefully dissected pharyngeal glands were mounted on stubs, gold coated, and viewed in a JEOL JSM-6360 scanning microscope.

\section{Results and discussion}

The pro- and postpharyngeal glands form the largest exocrine complex in the head of ants (Fig 1A). The propharyngeal gland occurs as a paired formation with a left and a right cluster of class-3 gland cells (classification of Noirot \& Quennedey, 1974), with each cluster opening anteriorly in the pharynx. The postpharyngeal gland consists of a few lobes, formed by an epithelium of class-1 gland cells, which open in a more posterior region of the pharynx (Fig 1B). A third but less conspicuous glandular formation that is associated with the pharyngeal region is 
the epithelial infrabuccal cavity gland. It has a thickness around $20 \mu \mathrm{m}$, and lines the anterior ventral wall of the pharynx, continuing into the anterior dorsal part of the infrabuccal cavity (Figs 2A,B). This infrabuccal cavity gland was first described in Monomorium pharaonis, and because of its anatomical position probably has a function related with food digestion (Eelen et al., 2004).

\section{Propharyngeal gland}

The paired propharyngeal gland appears as two raspberry-like clusters of approx. 30 cells at each side. The spherical secretory cells have a diameter of around 30-40 $\mu \mathrm{m}$ (Fig 1B). Each cell is connected to a slender duct cell, forming a bicellular unit (Fig 1C). The cell clusters are situated at the ventral side of the anterior pharynx, and occupy most of the space formed by the anterior downward bend of the pharynx (Figs 2A-C). In this anterior region, the pharynx lumen is slit-like with upward lateral margins. At the inner side of both lateral margins, more or less at the level of the implantation of the antennae, is a sieve plate where the individual ducts of the secretory units open and discharge their contents into the pharynx (Fig 2C).

The large secretory cells have a centrally located round nucleus with a diameter around 15 $\mu \mathrm{m}$ (Fig 3A). The most conspicuous cytoplasmic component is the well-developed granular endoplasmic reticulum, although also numerous electron-dense spherical secretory vesicles with a diameter up to $1.5 \mu \mathrm{m}$, as well as mitochondria, are found (Fig 3B). Characteristic for class-3 gland cells is the occurrence of an end apparatus that drains the secretion from the secretory cell into the cuticular duct formed by the duct cell. Its lumen has a diameter of $0.5-1 \mu \mathrm{m}$, and is lined by a fibrillar endocuticular layer that is surrounded by a sheath of $2 \mu \mathrm{m}$-long microvilli. Near the junction with the duct cell, the innermost layer lining the lumen is an electron-dense and continuous epicuticle, of which upon penetration into the secretory cell only a few thin strands remain (Fig 3C). The microvilli of the end apparatus can appear in a regular pattern (Fig 3C) in some cells, while in others it appears considerably distorted, with large extracellular spaces in between them (Fig 3D). The slender duct cells contain a reduced cytoplasm with almost no organelles. They have a small elongated nucleus of $5 \times 2 \mu \mathrm{m}$. At the site where the nucleus occurs, the slender duct cells show a local widening (Fig 1C). Their most conspicuous characteristic is the sinuous cuticle-lined duct, which has an internal diameter of $1 \mu \mathrm{m}$ and a wall thickness of 150 nm (Fig 3E).

The general morphology as well as the ultrastructural characteristics of the propharyngeal gland are in agreement with its occurrence in other ants (Phillips \& Vinson, 1980 for Solenopsis invicta; Gama \& Cruz-Landim, 1982 for several ant subfamilies; Billen \& Peusens, 1984 for Formicinae; Schoeters \& Billen, 1991 and Amaral \& Caetano, 2005 for Atta sexdens rubropilosa; Niculita et al., 2007 for Lasius niger; Billen et al., 2013 for Protanilla wallacei; Billen et al., 
2014 for Myrmoteras iriodum). The presence of a well-developed granular endoplasmic reticulum is entirely in line with its presumed function of elaborating digestive enzymes (Ayre, 1967), while the numerous electron-dense vesicles most likely correspond with this proteinaceous secretion. The cuticular composition of the end apparatus with a discontinuous epicuticle facilitates the draining of the secretory products from the cytoplasm into the duct. The occurrence of some secretory cells with a regular microvillar pattern in the end apparatus, and others with distorted microvilli, can be seen as different stages in the activity cycle (Billen \& Morgan, 1998). The propharyngeal gland of ants is homologous to the hypopharyngeal gland of honeybees, which produces the royal jelly (Cruz Landim \& Hadek, 1969). The propharyngeal gland has sometimes been given this name (Gama \& Cruz-Landim, 1982; Amaral \& Caetano, 2005), or in older literature erroneously has also been referred to as maxillary gland (Kürschner, 1971; Phillips \& Vinson, 1980), in spite of its clear opening into the pharynx.

\section{Postpharyngeal gland}

The postpharyngeal gland is formed by a few irregular lobes with a conspicuous globular external surface (Figs 1B, 4A). Although this appearance may give the initial impression of a cluster of rounded class-3 secretory cells, sectioning clearly confirms the epithelial nature of the gland wall as formed by class- 1 cells with a height of around $20 \mu \mathrm{m}$, albeit with obvious basal protrusions that have a diameter of 15-20 $\mu \mathrm{m}$ (Fig 4B,C). Each protrusion corresponds with the basal part of a cell, as illustrated by the ventral cell junctions that coincide with the margins of the globular surfaces (Fig 4C). The rounded nuclei have a diameter of $5 \mu \mathrm{m}$ and occur in a slightly basal position (Fig 4C). At their apical side, the cells are characterized by a clear microvillar border underneath the lumen-lining cuticle (Fig 4D,E). The cytoplasm contains a well-developed smooth endoplasmic reticulum and a variety of rounded secretory inclusions with a diameter of approximately $1 \mu \mathrm{m}$, which can be vesicular (Fig 4D), lamellar (Figs 4E,G) or electron-dense and granular (Fig 4G). The apical region of the lateral contacts with neighbouring cells displays septate junctions (Fig 4F). The basal cell membrane shows numerous invaginations (Fig 4H).

The ultrastructural organization of the postpharyngeal gland cells fully illustrates the features of an active gland tissue: significant surface increase through basal invaginations allows uptake of precursor molecules from the hemolymph, an extensive smooth endoplasmic reticulum in the cytoplasm allows the elaboration of a non-proteinaceous secretion, and microvilli represent an apical surface increase that facilitates discharge of the secretory products (Billen \& Morgan, 1998). Among social insects, only ants possess a postpharyngeal gland, which occurs in the three castes (workers, queens and males) of all species. Chemical analysis of the gland reveals the presence of hydrocarbons that are similar to those found on the external cuticle (Bagnères \& 
Morgan, 1991) and that underline its involvement in nestmate recognition. Besides this major function, the postpharyngeal gland has also been reported to play a role in several other functions, such as digestion, caste determination, and social food provisioning in the colony (reviewed in Delage-Darchen, 1976 and in Eelen et al., 2006). This involvement in various functions is possibly reflected in the various forms of secretory inclusions that can be observed.

A very peculiar feature of the postpharyngeal gland of Brachyponera sennaarensis is the globular appearance of the epithelium. A similar shape has so far only been reported for the postpharyngeal gland of two Dinoponera species (Schoeters \& Billen, 1997). The functional meaning of this globular cell shape as yet remains unknown. It hardly contributes to an increase of the cell surface (the existing basal invaginations are more effective in this regard), but may be related to the general structural integrity of the gland. The presence of septate junctions in the lateral junctions can also be interpreted as a structure that provides mechanical strength. At the general anatomical level, the postpharyngeal gland usually has a glove-shaped appearance with numerous finger-like tubules (Kürschner, 1971; Phillips \& Vinson, 1980; Schoeters \& Billen, 1991; Niculita et al., 2007). In a survey study of 18 species representing 5 subfamilies, Gama \& Cruz Landim (1982) described tubular postpharyngeal glands in Dorylinae, Formicinae, and Myrmicinae and lobed glands in Pseudomyrmecinae and Ponerinae. Among the 4 ponerine species studied by these authors, however, the lobed appearance was only found in 3 (Neoponera villosa, Odontomachus chelifer and Pachycondyla striata), whereas Ectatomma brunneum has tubular postpharyngeal glands. This is interesting, as Ectatomma at that time was classified among the Ponerinae, from which it has later been removed to become a member of the new subfamily Ectatomminae (Bolton, 2003). Gland anatomy, such as the difference between tubular versus lobed postpharyngeal glands, and in this case also its globular cell shape, thus here nicely supports phylogeny.

\section{Acknowledgements}

We are very grateful to An Vandoren for her help in section preparation and to Alex Vrijdaghs for his assistance with scanning microscopy. We also extend our sincere appreciation to the Deanship of Scientific Research at King Saud University for funding the work through the research group project $\mathrm{N}^{\circ} 340$.

\section{References}


Al-Anazi, M., Al-Ashahrani, M. \& Al-Salamah, M. (2009). Black ant stings caused by Pachycondyla sennaarensis: a significant health hazard. Annals of Saudi Medicine 29: 207-211. Al-Khalifa, M.S., Ahmed, A.M., Mashaly A.M.A., Al-Mekhalfi, F.A., Khalil, G., Siddiqui, M.I. \& Ali, M.F. (2010). Studies on the distribution of Pachycondyla sennaarensis (Hymenoptera: Formicidae: Ponerinae) in Saudi Arabia. 1. Ar-Riyadh Region. Pakistan Journal of Zoology, 42: 707-713.

Amaral, J.B. \& Caetano, F.H. (2005). The hypopharyngeal gland of leaf-cutting ants (Atta sexdens rubropilosa) (Hymenoptera: Formicidae). Sociobiology, 46: 515-524.

Ayre, G.L. (1967). The relationships between food and digestive enzymes in five species of ants (Hymenoptera: Formicidae). The Canadian Entomologist, 99: 408-411.

Bagnères, A.G. \& Morgan, E.D. (1991). The postpharyngeal gland and the cuticle of Formicidae contain the same characteristic hydrocarbons. Experientia, 47: 106-111.

Billen, J. \& Peusens, G. (1984). Ultrastructure de la glande propharyngienne chez les fourmis formicines (Hymenoptera, Formicidae). Actes des Colloques Insectes Sociaux, 1: 121-129.

Billen, J. \& Morgan, E.D. (1998). Pheromone communication in social insects - sources and secretions. In R.K. Vander Meer, M.D. Breed, M.L. Winston \& K.E. Espelie (Eds), Pheromone Communication in Social Insects: Ants, Wasps, Bees and Termites (pp. 3-33). Boulder: Westview Press.

Billen, J., Bauweleers, E., Hashim, R. \& Ito, F. (2013). Survey of the exocrine system in Protanilla wallacei (Hymenoptera, Formicidae). Arthropod Structure and Development 42: 173183.

Billen, J., Mandonx, T., Hashim, R. \& Ito, F. (2014). Exocrine glands of the ant Myrmoteras iriodum. Entomological Science, DOI: 10.1111/ens.12107

Bolton, B. (2003). Synopsis and classification of Formicidae. Memoirs of the American Entomological Institute, 71: 1-374.

Cruz Landim, C. \& Hadek, R. (1969). Ultrastructure of Apis mellifera hypopharyngeal gland. Proc. 6th Int. Congress IUSSI, Bern, pp. 121-130. 
Delage-Darchen, B., (1976). Les glandes post-pharyngiennes des fourmis. Connaissances actuelles sur leur structure, leur fonctionnement, leur rôle. Annales de Biologie, 15: 63-76. Eelen, D., Børgesen, L.W. \& Billen, J. (2004). Morphology of a novel glandular epithelium lining the infrabuccal cavity in the ant Monomorium pharaonis (Hymenoptera, Formicidae). Arthropod Structure and Development, 33: 471-475.

Eelen, D., Børgesen, L.W. \& Billen, J. (2006). Functional morphology of the postpharyngeal gland of queens and workers of the ant Monomorium pharaonis (L.). Acta Zoologica (Stockholm), 87: 101-111.

Gama, V. \& Cruz Landim, C. (1982). Estudo comparativo das glândulas do sistema salivar de formigas (Hymenoptera, Formicidae). Naturalia, 7: 145-165.

Kürschner, I. (1971). Zur Anatomie von Formica pratensis Retzius, 1783. Morphologische Untersuchungen der sekretorischen Kopfdrüsen (Postpharynxdrüse, Maxillardrüse, Mandibulardrüse, Zungendrüse) under der am Kopf ausmündenden Labialdrüse. Beiträge der Entomologie, 21: 191-210.

Lachaud, J.P. \& Dejean, A. (1994). Predatory behavior of a seed-eating ant: Brachyponera senaarensis. Entomologia Experimentalis et Applicata, 72: 145-155.

Levieux J. \& Diomande, T. (1978). La nutrition des fourmis granivores. II. Cycle d'activité et régime alimentaire de Brachyponera senaarensis (Mayr) (Hymenoptera, Formicidae). Insectes Sociaux, 25: 187-196.

Niculita, H., Billen, J. \& Keller, L. (2007). Comparative morphology of cephalic exocrine glands among castes of the black ant Lasius niger. Arthropod Structure and Development, 36: 135-141. Noirot, C. \& Quennedey, A. (1974). Fine structure of insect epidermal glands. Annual Review of Entomology, 19: 61-80.

Paknia, O. (2006). Distribution of the introduced ponerine ant Pachycondyla sennaarensis (Hymenoptera: Formicidae) in Iran. Myrmecologische Nachrichten, 8: 235-238.

Phillips, S.A. \& Vinson, S.B. (1980). Comparative morphology of glands associated with the head among castes of the red imported fire ant, Solenopsis invicta Buren. Journal of the Georgia Entomological Society, 15: 215-226. 
213 Schoeters, E. \& Billen, J. (1991). Morphologie des glandes pro- et postpharyngiennes chez Atta 214 sexdens. Actes des Colloques Insectes Sociaux, 7: 153-160.

215 Schoeters, E. \& Billen, J. (1997). The postpharyngeal gland in Dinoponera ants (Hymenoptera:

216 Formicidae): unusual morphology and changes during the secretory process. International Journal 217 of Insect Morphology and Embryology, 25: 443-447.

218 Wetterer, J.K. (2013). Geographical spread of the samsum or sword ant, Pachycondyla

219 (Brachyponera) sennaarensis (Hymenoptera: Formicidae). Myrmecological News, 18: 13-18. 


\section{Figure legends}

Fig. 1. Scanning electron micrographs of the pharyngeal glands of Brachyponera sennaarensis workers. A. Frontal view of the head with dissected pharyngeal glands (enlarged in B) shown at the same magnification. B. Ventral view of pharynx (ph) with attached pro(ProPG) and postpharyngeal glands (PPG). C. Detail of secretory cells (SC) and slender duct cells (DC) of propharyngeal gland. Arrows indicate local widening of duct cells in region where duct cell nucleus occurs.

Fig. 2. Semithin longitudinal sections through propharyngeal gland: (A) at the body midline, (B) at the level of the lateral pharyngeal margin, showing the anterior bend of the pharynx. In both $\mathrm{A}$ and $\mathrm{B}$, the anterior side is to the left. White arrows indicate gland ducts, black arrows show end apparatus in secretory cells. Double black arrows indicate epithelial infrabuccal cavity gland. C. Cross section at the level indicated by the dashed line in figure A, showing the grouped occurrence of the ducts and their opening into the pharynx through a lateral sieve plate at each side (black arrowheads). AI: antennal implantation, IBC: infrabuccal cavity, MF: muscle fibres, ph: pharynx, SC: secretory cells.

Fig. 3. Electron micrographs of the propharyngeal gland. A. Survey of rounded secretory cells with centrally located spherical nucleus. B. Cytoplasmic detail showing well-developed granular endoplasmic reticulum. C. Detail of end apparatus with regular microvillar organization near junction with duct cell (white arrow points to continuous epicuticle near junction with duct cell, black arrows indicate regions with separated epicuticle). D. Detail of end apparatus with distorted microvillar organization. E. Detail of duct cell with very scarce cytoplasm. Arrows indicate junction with second duct cell (the 2 ducts at the right side represent sections of the same sinuous duct within a single duct cell). d: ducts, DC: duct cell, EA: end apparatus, M: mitochondria, mv: microvilli, N: nucleus, RER: granular endoplasmic reticulum, SV: secretory vesicle.

Fig. 4. Postpharyngeal gland. A. Scanning micrograph of globular external surface. B. Semithin section showing globular shape of gland epithelium. C-H: Electron migrographs. C. Survey of globular epithelium, arrowheads indicate where ventral cell junctions occur. $\mathbf{D}$. 

Intercellular contact region with septate junctions. G. Cytoplasmic detail with lamellar and granular secretion. $\mathbf{H}$. Basal cytoplasm showing numerous basal invaginations. bi: basal invaginations, bm: basement membrane, ct: cuticle, GS: granular secretion, LD:
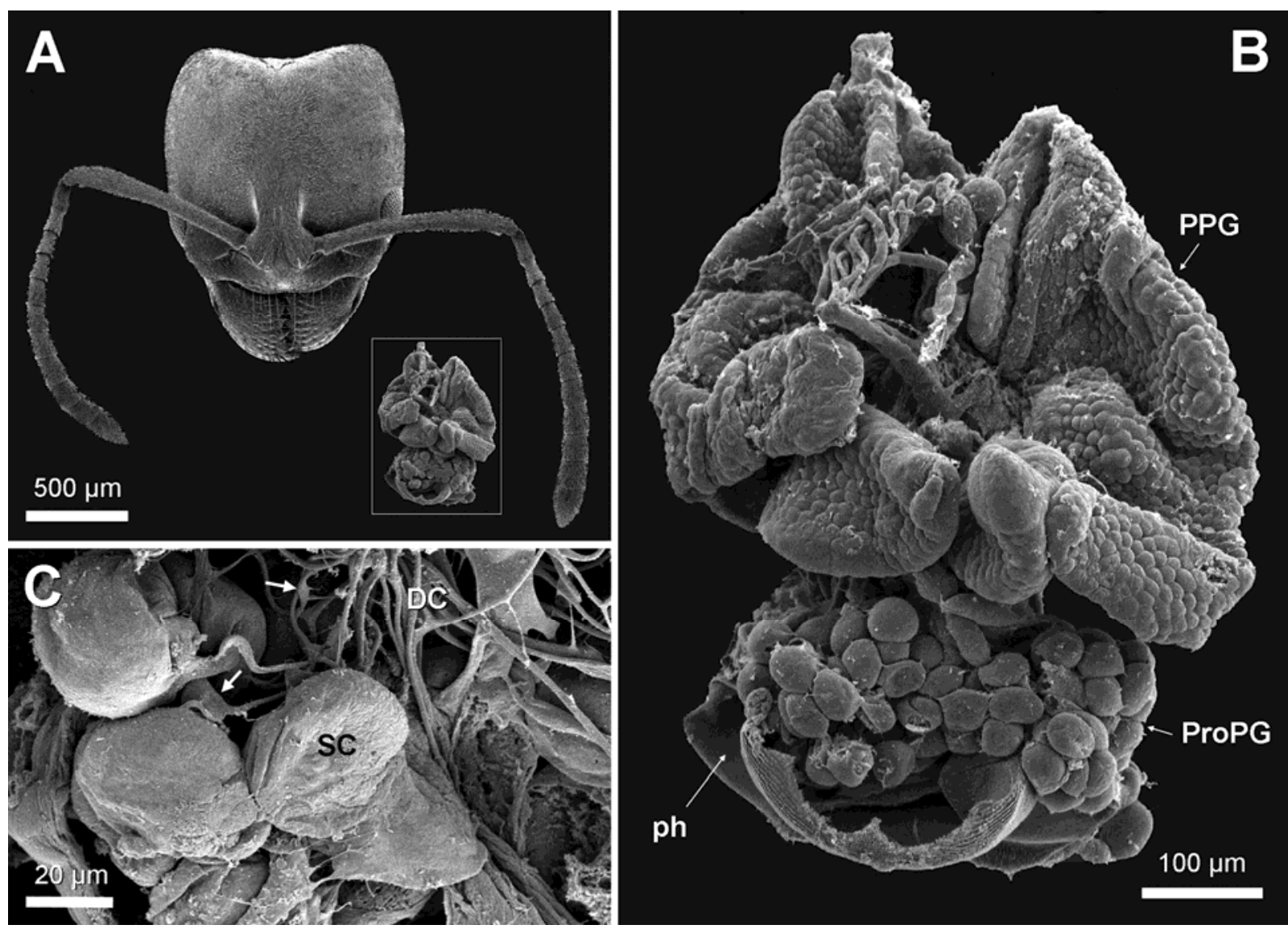

Fig. 1 

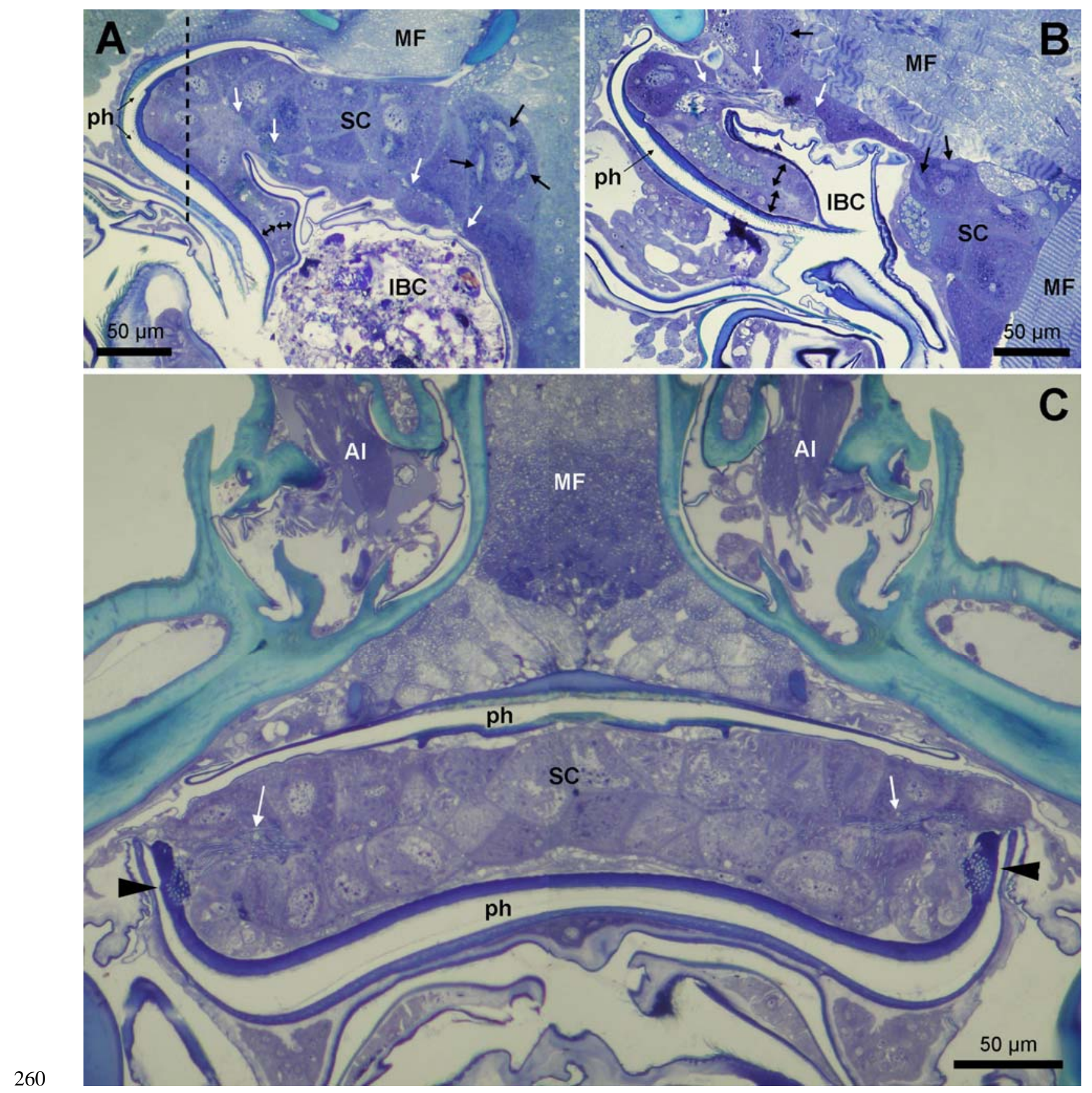

$261 \quad$ Fig. 2 


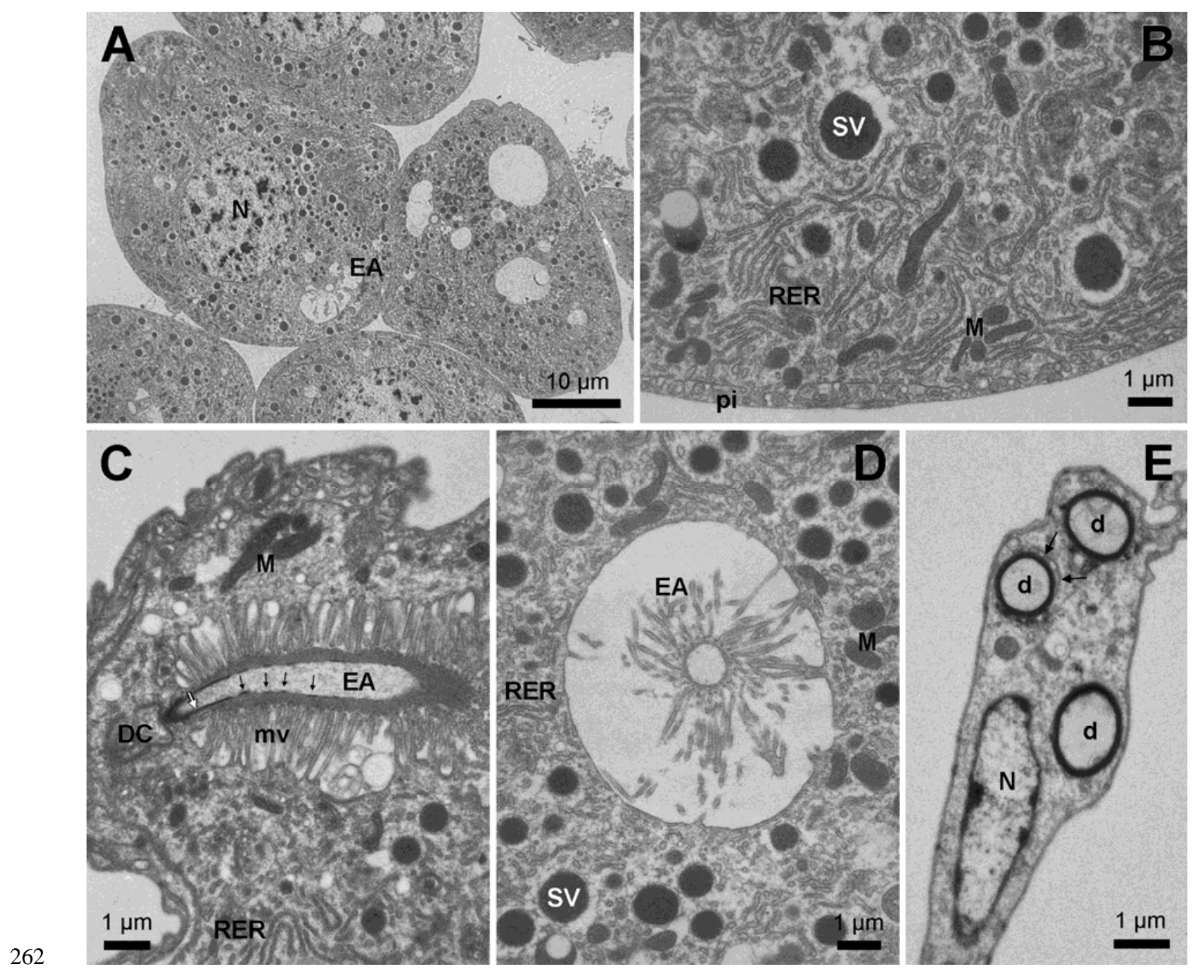

Fig. 3 

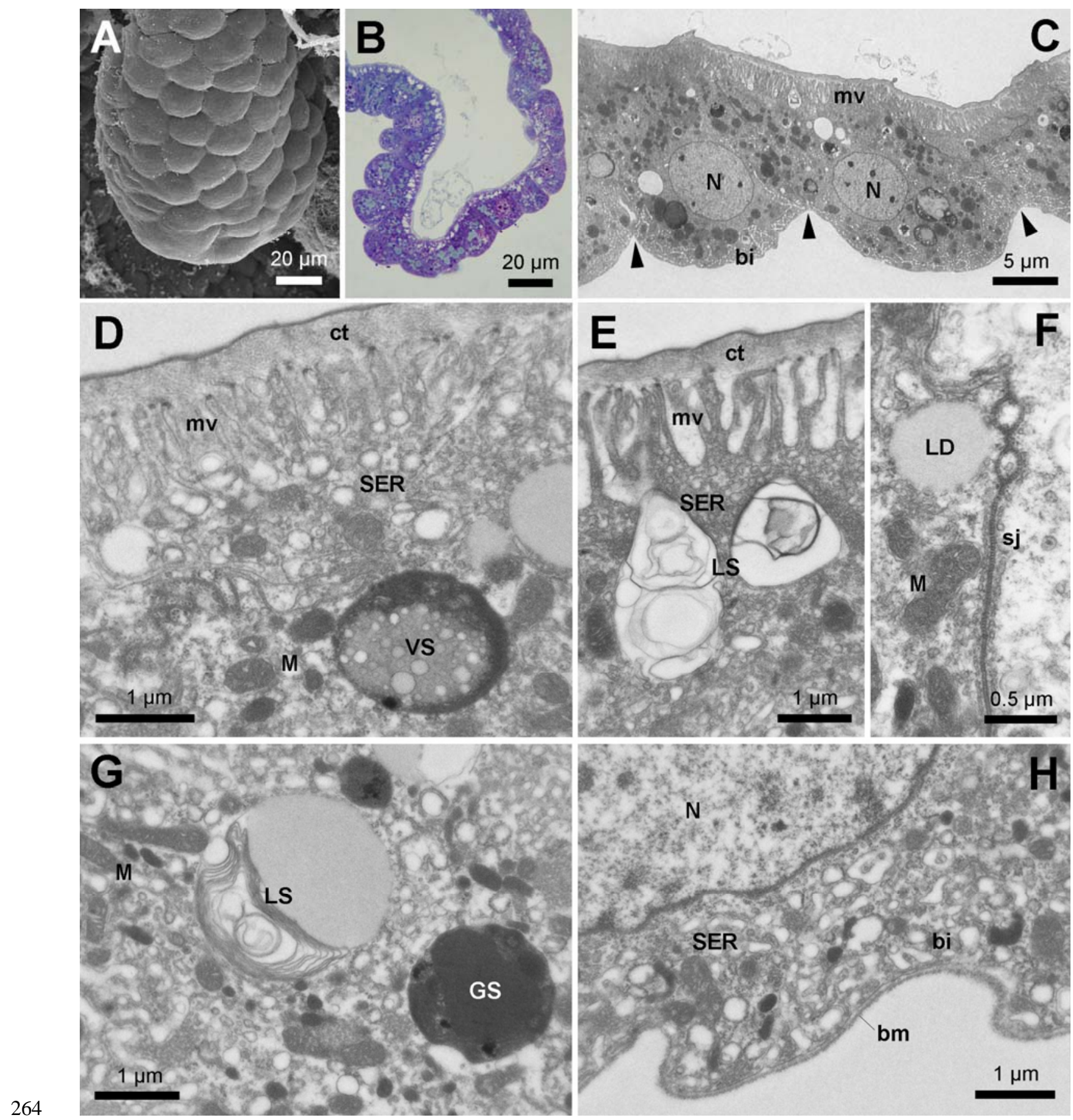

Fig. 4 